\title{
HAK PENAMBANGAN PASIR OLEH MASYARAKAT LOKAL DI KECAMATAN PLOSOKLATEN KABUPATEN KEDIRI
}

\author{
ACHMAD BAHRONI
}

Fakultas Hukum Universitas Kadiri

Jl. Selomangleng No. 1 Kediri

\begin{abstract}
ABSTRAK
Penelitian ini bertujuan untuk mengetahui dasar hukum masyarakat lokal dalam melakukan kegiatan penambangan pasir, mengetahui pandangan masyarakat setempat terhadap kegiatan penambangan pasir di Kecamatan Plosoklaten Kabupaten Kediri dan mengetahui kebijakan pemerintah terhadap pelaksanaan hak dan kewajiban atas kegiatan penambangan pasir di Kecamatan Plosoklaten Kabupaten Kediri. Obyek penelitian ini dilakukan di wilayah Kabupaten Kediri, tepatnya di Kecamatan Plosoklaten Kabupaten Kediri, dengan cara pengumpulan data ada dua cara, yaitu metode penelitian kepustakaan dan lapangan yang terdiri dari wawancara dan observasi dilapangan. Data yang dipergunakan dalam penelitian adalah data Primer yaitu data yang diperoleh langsung dari lapangan dengan menggunakan teknik wawancara, dan data sekunder berupa studi kepustakaan.

Analisis data yang digunakan adalah analisis kualitatif dengan penarikan kesimpulan secara deskriptif, dan hasil penelitian yang diperoleh adalah dasar hukum penguasaan oleh masyarakat lokal terhadap kegiatan penambangan pasir yang dilakukan di Kecamatan Plosoklaten Kabupaten Kediri yaitu penguasaan secara fisik yag terjadi secara alamiah dan turun temurun, tetapi dasar hukum penguasaan secara fisik saja tidak cukup untuk mengolah dan memanfaatkan sumber daya alam yang ada dalam hal ini masyarakat yang penambangan pasir harus mempunyai ijin Pertambangan Rakyat (IPR) yang diberikan oleh pemerintah setempat dalam hal ini pemerintah daerah Kabupaten Kediri seperti yang tercantum dalam Pasal 1 Ayat 10 Undang-undang No. 4 Tahun 2009 tentang Pertambangan Mineral dan Batu Bara.
\end{abstract}

Kata Kunci : $\quad$ Hak Penambang Pasir, Masyarakat Lokal, Hukum Publik

\section{LATAR BELAKANG}

Bahwa negara kita Indonesia merupakan negara yang kaya akan bahan galian (tambang), yaitu antara lain meliputi emas, perak, tembaga, minyak dan gas bumi, batu bara dan lain-lain. Bahan itu dikuasai oleh negara, dan hak penguasaan Negara berisi wewenang untuk mengatur, mengurus dan mengawasi pengelolaan atau pengusahaan bahan galian, serta berisi kewajiban untuk mempergunakannya sebesarbesarnya untuk kemakmuran rakyat. Penguasaan oleh negara diselenggarakan oleh pemerintah. Hak menguasai tanah oleh Negara tercantum dalam ketentuan Pasal 33

Achmad Bahroni, Hak Penambangan Pasir OLeh Masyarakat Lokal Di Kecamatan Plosoklaten Kabupaten kediri 
Undang-undang Dasar 1945 yang menyatakan bahwa "bumi dan air dan kekayaan alam yang terkandung di dalamnya dikuasai oleh negara dan dipergunakan untuk sebesar-besarnya kemakmuran rakyat". Hal ini menunjukkan bahwa pemanfaatan bumi, air, dan kekayaan alam didalamnya semata-mata untuk menyejahterakan rakyat dengan memperhatikan aspek keadilan, bukan untuk orang tertentu tetapi rakyat banyak.

Terkait pegelolaan sumber daya alam khususnya tentang pertambangan berlakunya Undang-undang Nomor 32 Tahun 2004 pasal 4 ayat 4 tentang pemerintahan Daerah, yaitu :"Urusan Pemerintahan bidang energi dan sumber daya mineral sebagaimana dimaksud pada ayat (1) yang berkaitan dengan pemanfaatan langsung panas bumi dalam Daerah kabupaten" memberikan kewenangan pengelolaan sumber daya alam khususnya pertambangan mineral. Bahwa dari terjadinya letusan gunung Kelud telah menghasilkan luapan lahar yang berbentuk pasir dan batu di daerah kecamatan Plosoklaten Kabupaten Kediri. Pasir dan batu yang berasal dari letusan gunung tersebut sudah menjadi sumber penghasilan bagi warga kecamatan Plosoklaten. Proses penambangan pasir dan batu yang dilakukan oleh warga secara turun temurun dengan cara tradisonal yang sudah dilakukan sejak dahulu dari nenek moyangnya yang dianggapnya bahwa yang dilakukan selama ini adalah sudah benar.

Disisi lain pemerintah pembentuk kebijakan telah membuat peraturanperaturan perundang-undangan yang terkait dengan pertambangan dan mineral Undang-undang No. 4 Tahun 2009 tentang pertambangan Mineral dan Batu bara. Dalam Pasal 1 Undang-undang nomor 4 Tahun 2009 menyatakan bahwa "Izin Pertambangan Rakyat, yang selanjutnya disebut IPR, adalah izin untuk melaksanakan usaha pertambangan dalam wilayah pertambangan rakyat dengan luas wilayah dan investasi terbatas ". Kegiatan pertambangan rakyat dalam Undangundang tersebut dilaksanakan dalam suatu wilayah pertambangan rakyat sesuai ketentuan dalam pasal 20 Undang-undang Nomor 4 Tahun 2009 tentang pertambangan mineral dan batu bara. Secara substansi pihak pemerintah telah membuat peaturan-peraturan yang terkait tentang permasalahan pertambangan, akan tetapi dalam penerapan hukum yang ada juga dipengaruhi oleh faktor aparat penegak

Achmad Bahroni, Hak Penambangan Pasir OLeh Masyarakat Lokal Di Kecamatan Plosoklaten Kabupaten kediri 
hukum dan peran masyarakat luas yang ikut mendukung penegakan hukum. Bahwa bekerjanya hukum adalah menyatukan tiga faktor yang berperan penting yaitu Faktor pembuat undang-undang yang dalam hal ini adalah legislatif, faktor pelaksana undang-undang dalam hal ini adalah eksekutif dan Faktor sosial lain yang juga memegang peran, yaitu masyarakat dalam hal ini menyangkut kesadaran hukum masyarakat.

Setiap usaha pertambangan Bahan Galian Golongan C di wilayah sungai dilaksanakan setelah mendapatkan izin dari Gubernur. (2) Izin Pertambangan sebagaimana dimaksud ayat (1) diberikan untuk kegiatan : a. Eksploitasi; b. Pengangkutan. (3) Izin diberikan kepada Koperasi yang anggotanya berasal dari masyarakat setempat, diketahui oleh Kepala Desa/Lurah dan Camat setempat.

\section{RUMUSAN MASALAH}

Berdasarkan latar belakang tersebut diatas maka masalah pokok yang akan diteliti adalah :

1. Apakah dasar hukum bagi masyarakat lokal dalam melakukan penambangan pasir?

2. Bagaimanakah kebijakan pemerintah terhadap pelaksanaan hak dan kewajiban atas kegiatan penambangan pasir di Kecamatan Plosoklaten Kabupaten Kediri?

\section{LANDASAN TEORI}

Pada bagian ini diuraiakan kerangka teori yang digunakan dalam penelitian. Maksudnya, penjelaskan aliran jalan pemikiran penelitian disesuai dengan kerangka teori yang logis. Untuk itu, masukkan identifikasi masalah yang telah ditetapkan ke dalam kerangka teori yang sesuai agar masalah-masalah yang diidentifikasi menjadi jelas. Cara berpikir yang bisa digunakan adalah dengan kerangka berpikir deduktif, yaitu menjelaskan dari hal-hal yang bersifat umum, lalu mengerucut ke hal-hal yang lebih spesifik. Hal-hal yang bersifat umum adalah teori-teori (dalil, hukum, kaidah, dan sebagainya), sedangkan hal-hal yang bersifat spesifik adalah masalah yang telah diidentifikasi (Subyantoro dan Suwarto, 2007: 120-121).

Istilah hukum pertambangan merupakan terjemahan dari bahasa inggris, yaitu mining law. Menurut Ensiklopedia Indonesia, Hukum Pertambangan adalah :"Hukum

Achmad Bahroni, Hak Penambangan Pasir OLeh Masyarakat Lokal Di Kecamatan Plosoklaten Kabupaten kediri 
yang mengatur tentang penggalian atau pertambangan bijih-bijih dan mineral-mineral dalam tanah". Bahwa usaha pertambangan yang dilakukan oleh rakyat pada prinsipnya merupakan salah satu bentuk kegiatan ekonomi rakyat didaerah-daerah yang terdapat bahan galian dan tambang. Kegiatan tersebut merupakan upaya bagi masyarakat setempat sebagai salah satu penopang kebutuhan ekonomi masyarakat, namun disisi lain kegiatan penambangan juga akan berpengaruh terhadap terganggunya keseimbangan lingkungan apabila tidak dilakukan melalui prosedur yang benar.

Terkait hal tersebut guna menjaga keseimbagan lingkungan diperlukan peran pemerintah baik pusat dan daerah untuk mengatur kegiatan-kegiatan yang berhubungan dengan pertambangan rakyat. Kontrol pemerintah melalui mekanisme perizinan merupakan upaya dari pemerintah untuk menjaga keberlangsungan dan keseimbangan lingkungan daerah tambang. Menurut Sjachran Basah istilah izin adalah perbuatan hukum Negara yang bersegi satu yang mengaplikasikan peraturan dalam hal konkrit berdasarkan persyaratan dan prosedur sebagaimana diterapkan oleh ketentuan perundang-undangan yang berlaku. Selanjutnya perizinan memiliki kekuatan dan kepastian haru memenuhi unsur-unsur Perizinan diantaranya $:^{1}$

1. Instrumen yuridis, Izin merupakan instrument yuridis dalam bentuk ketetapan yang bersifat konstitutif dan yang digunakan oleh pemerintah untuk menghadapi atau mentapkan peristiwa konkret,sebagai ketetapan izin itu dibuat dengan ketentuan dan persyaratan yang berlaku pada ketetapan pada umumnya.

2. Peraturan perundang-undangan

3. Pembuatan dan penerbitan ketetapan izin merupakan tindakan hukum permerintahan,sebagai tindakan hukum maka harus ada wewenang yang diberikan oleh peraturan perundang-undangan atau harus berdasarkan pada asas legalitas, tanpa dasar wewenang, tindakan hukum itu menjadi tidak sah,oleh karena itu dalam hal membuat dan menerbitkan izin haruslah didasarkan pada wewenang yang diberikan oleh peraturan peruUUan yang berlaku, karena tanpa adanya dasar wewenang tersebut ketetapan izin tersebut menjadi tidak sah.

4. Organ pemerintah

Achmad Bahroni, Hak Penambangan Pasir OLeh Masyarakat Lokal Di Kecamatan Plosoklaten Kabupaten kediri 
Organ pemerintah adalah organ yang menjalankan urusan pemerintah baik di tingkat pusat maupun di tingkat daerah.menurut sjahran basah,dari badan tertinggi sampai dengan badan terendah berwenang memberikan izin.

5. Peristiwa kongkret

Izin merupakan instrument yuridis yang berbentuk ketetapan yang digunakan oleh pemerintah dalam menghadapi peristiwa kongkret dan individual,peristiwa kongkret artinya peristiwa yang terjadi pada waktu tertentu, orang tertentu ,tempat tertentu dan fakta hukum tertentu.

6. Prosedur dan persyaratan

Pada umumnya permohonan izin harus menempuh prosedur tertentu yang ditentukan oleh pemerintah,selaku pemberi izin. Selain itu pemohon juga harus memenuhi persyaratan-persyaratan tertentu yang ditentukan secara sepihak oleh pemerintah atatu pemberi izin.prosedur dan persyaratan perizinan itu berbedabeda tergantung jenis izin, tujuan izin, dan instansi pemberi izin. Menurut soehino,syarat-syarat dalam izin itu bersifat konstitutif dan kondisional, konstitutif, karena ditentuakn suatu perbuatan atau tingkah laku tertentu yang harus (terlebih dahulu) dipenuhi,kondisional, karena penilaian tersebut baru ada dan dapat dilihat serta dapat dinilai setelah perbuatan atau tingkah laku yang disyaratkan itu terjadi.

\section{METODOLOGI PENELITIAN}

\section{Teknik Pengumpulan Data}

Untuk data primer dilakukan dengan wawancara langsung kepada Masyarakat di Desa Pranggang Kecamatan Plosoklaten Kabupaten Kediri dan pengamatan secara langsung pada masyarakat adat setempat. Sedangkan data sekunder diperoleh dengan studi kepustakaan yaitu pengumpulan data melalui literatur dan dokumen lain yang berkaitan dengan permasalahan yang ada.

\section{Analisa Data}

Data yang diperoleh kemudian dianalisa dengan menggunakan metode deskriptif kualitatif yaitu suatu analisis yang sifatnya menjelaskan atau menggambarkan mengenai peraturan-peraturan yang berlaku yang terkait dengan

Achmad Bahroni, Hak Penambangan Pasir OLeh Masyarakat Lokal Di Kecamatan Plosoklaten Kabupaten kediri 
pertambangan pasir dan perizinan terhadap praktek pertambangan pasir didaerah kecamatan Plosoklaten.

\section{HASIL PENELITIAN DAN PEMBAHASAN}

\section{Profil Lokasi Penelitian}

Wilayah Kabupaten Kediri secara geografis terletak pada koordinat antara 111047'05 - 112o 18'20" Bujur Timur dan 7o 36' 12" - 8o 0'32" Lintang selatan. Kabupaten Kediri dengan propinsi Jawa Timur diapit oleh 5 kabupaten . Luas wilayah Kabupaten Kediri adalah sekitar 1.386,05 $\mathrm{km}^{2}$ atau $+5 \%$ dari luas wilayah propinsi Jawa Timur di mana $240,88 \mathrm{~km}^{2}$ diantaranya merupakan wilayah pesisir, pertanian, dan perkebunan. Penelitian ini dilakukan di Kecamatan Plosoklaten yang berada di sebelah timur Kantor Kabupaten Kediri. Secara Geografis Kecamatan Plosoklaten cukup strategis dengan luas wilayah $88,59 \mathrm{~km}^{2}$, Kecamatan Plosoklaten terbagi atas 15 (lima belas) Kelurahan, ada beberapa desa yang letaknya di daerah perbukitan (dataran tinggi) dan ada yang berada di dataran rendah, batas wilayah sebelah barat Kecamatan Pare dan Gurah, sebelah utara kecamatan Puncu, sebelah timur Gunung Kelud serta sebelah selatan Kecamatan Wates

Penduduk di Kecamatan Plosoklaten memiliki mata pencaharian sebagai petani, selain itu adapula yang bekerja sebagai Pegawai Negeri Sipil, Wiraswasta, Buruh dan sebagai penambang pasir. Secara administratif letak Kecamatan Plosoklaten berbatasan dengan:

Sebelah Utara berbatasan dengan kecamatan Puncu

Sebelah Timur berbatasan dengan Gunung Kelud.

Sebelah Selatan berbatasan dengan Kecamatan Wates

Sebelah Barat berbatasan dengan Kecamatan Gurah dan Pare

Lokasi penelitian terletak di sepanjang aliran sungai yang melintasi Kelurahan Pranggang dan Wonorejo Trisulo. Sungai tersebut dikenal dengan nama Sungai Ngobo yang melintasi beberapa Kecamatan di Kabupaten kediri.

\section{Dasar Hukum Masyarakat Lokal Melakukan Penambangan Pasir}

Achmad Bahroni, Hak Penambangan Pasir OLeh Masyarakat Lokal Di Kecamatan Plosoklaten Kabupaten kediri 
Berdasarkan sejarah, kegiatan penambangan pasir di Kecamatan Plosoklaten telah berlangsung sekitar tahun 1990, Kegiatan penambangan pasir yang dilakukan oleh masyarakat lokal berada di Kelurahan Pranggang dan Kelurahan Wonorejo Trisulo, wilayah kelurahan ini berbatasan dengan sungai Ngobo, kegiatan penambangan pasir tersebut dilakukan di sepanjang aliran sungai dan di tebingtebing sungai. Awalnya masyarakat lokal melakukan penambangan pasir karena melihat potensi sumber daya alam yang dapat dijadikan penghasilan tambahan untuk memenuhi kebutuhan hidup. Hal tersebut merupakan tuntutan ekonomi mengingat masyarakat di daerah ini tergolong ke dalam masyarakat yang tingkat perekonomiannya menengah ke bawah. Hal ini dapat diketahui dari kehidupan sehari-hari mereka, di mana tingkat pendidikan dan pekerjaan/penghasilan masih kurang bahkan ada masyarakat yang menjadikan kegiatan menambang pasir sebagai mata pencaharian utama.

Hak penambangan pasir masyarakat lokal terjadi secara alamiah, yakni pemerintah setempat mengetahui kegiatan penambangan pasir yang dilakukan oleh masyarakat lokal. Hal tersebut diungkapkan oleh Budi Santoso yang merupakan Kepala Lingkungan di Kelurahan Sepawon mengatakan bahwa kegiatan penambangan pasir tersebut telah berlangsung secara turun temurun dan telah berlangsung kurang lebih 20 Tahun (Wawancara, Jumat 27 Oktober 2017).

Kegiatan penambangan pasir tersebut dilakukan di sepanjang aliran sungai Ngobo dan tebing-tebing sungai, penambang pasir menyelam ke dasar sungai untuk mengambil pasir dengan menggunakan alat-alat yang sederhana dan teknologi yang tidak begitu canggih, seperti skop dibantu dengan alat muat keranjang rotan. Kegiatan pertambangan yang dilakukan oleh masyarakat lokal tersebut diketahui oleh pemerintah setempat. Namun dalam kegiatan pertambangan harus tetap memperhatikan berbagai aspek seperti lingkungan dan rencana tata ruang wilayah.

Dasar penguasaan para penambang pasir yakni penguasaan secara fisik yaitu penguasaan yang menunjukkan adanya hubungan langsung antara objek/wilayah tambang dan penambang pasir. Namun dasar hukum penguasaan secara fisik saja

Achmad Bahroni, Hak Penambangan Pasir OLeh Masyarakat Lokal Di Kecamatan Plosoklaten Kabupaten kediri 
tidak memiliki kekuatan hukum yang kuat, harus memiliki alas hak atau penguasaan secara yuridis yakni, hubungan tersebut ditunjukkan dengan adanya alas hak dari penguasaan objek yang dikuasai. Dalam hal ini penambang pasir harus mempunyai Izin Pertambangan Rakyat (IPR) yang diberikan oleh pemerintah setempat seperti yang tercantum dalam Pasal 1 Ayat 10 Undang-Undang Nomor 4 Tahun 2009 tentang Pertambangan Mineral dan Batu bara.

Dalam hal pemberian Izin Pertambangan Rakyat (IPR) menjadi kewenangan pemerintah Kabupaten Kediri dalam pengelolaan pertambangan mineral dan batu bara. Lokasi dari kegiatan penambangan pasir di Kecamatan Plosoklaten bisa ditetapkan sebagai Wilayah Pertambangan Rakyat (WPR) karena mempunyai cadangan mineral sekunder yang terdapat di sungai dan/atau di antara tepi sungai, hal ini sesuai dengan Pasal 22 Undang-Undang No. 4 Tahun 2009 tentang Pertambangan Mineral dan Batu bara.

Berdasarkan hasil wawancara dengan 5 orang penambang pasir sebagai responden pada hari Senin tanggal 30 Oktober 2017, peneliti memperoleh data sebagai berikut:

1. Sungging Kurniawan umur 37 tahun, mata pencaharian utama sebagai penambang pasir dan telah melakukan kegiatan penambang pasir selama 10 Tahun yang merupakan penambang tetap di lokasi tersebut.

2. Supali umur 50 Tahun, mata pencaharian utama sebagai penambang pasir dan telah melakukan kegiatan penambangan pasir selama 20 Tahun yang merupakan penambang tetap di lokasi tersebut. Pengambilan/penambangan pasir tesebut tidak dikenai pajak dari pemerintah setempat, Supali hanya membayar sebesar Rp. 5.000,- kepada pemilik tanah untuk menimbun pasir yang telah ditambang untuk di angkut oleh truk.

3. Budi Santoso umur 52 Tahun, mata pencaharian utama sebagai petani dan menambang pasir sebagai usaha sampingan. Budi Santoso telah melakukan kegiatan penambang pasir selama 20 Tahun yang merupakan penambang tetap di lokasi tersebut. Menurut Budi pembayaran pajak/redtribusi pernah diberlakukan

Achmad Bahroni, Hak Penambangan Pasir OLeh Masyarakat Lokal Di Kecamatan Plosoklaten Kabupaten kediri 
oleh Kepala Lingkungan, akan tetapi setelah Kepala Lingkungan di terganti penarikan pembayaran pajak/redtribusi sudah tidak diberlakukan lagi.

4. Nur Kamil umur 50 Tahun, mata pencaharian utama sebagai petani dan menambang pasir sebagai usaha sampingan. Nur Kamil telah melakukan kegiatan penambang pasir selama 10 Tahun yang merupakan penambang tetap di lokasi tersebut. Nur Kamil membayar redtribusi kepada Kepala Lingkungan sebesar Rp. $5.000,-$ / truk.

5. Saiful Anwar umur 56 Tahun, mata pencaharian utama sebagai petani dan menambang pasir sebagai usaha sampingan. Saiful Anwar telah melakukan kegiatan penambang pasir selama 10 Tahun yang merupakan penambang tetap di lokasi tersebut dan membayar redtribusi kepada Kepala Lingkungan. Menurut Saiful Anwar aparat pemerintah dari Dinas Perindustrian Perdagangan Pertambangan dan Energi Kabupaten Kediri telah melakukan peneguran secara lisan terhadap kegiatan penambangan pasir tersebut akan tetapi para penambang pasir tidak mengindahkan teguran tersebut dan tetap melakukan kegiatannya.

Semua responden di atas tidak mengetahui bahwa pada dasarnya kegiatan penambangan pasir yang mereka lakukan adalah Pertambangan Rakyat yang di atur dalam Undang-Undang No. 4 Tahun 2009 Tentang Pertambangan Mineral dan Batu bara, karena mereka tidak pernah diberikan sosialisasi oleh pemerintah sehingga para penambang tidak mengetahui hak dan kewajiban mereka dalam melakukan kegiatannya. Hal ini harus menjadi perhatian khusus oleh pemerintah setempat agar fungsi lingkungan hidup tetap terjaga kelestariannya sehingga tidak berdampak buruk terhadap masyarakat dan lingkungan hidup dan tetap memperhatikan kondisi dan hak-hak masyarakat lokal yang melakukan kegiatan penambangan pasir.

\section{Harapan Atau Pandangan Masyarakat Atas Kegiatan Pertambangan Pasir}

Manusia dalam hidupnya mempunyai hubungan secara timbal balik dengan lingkungannya baik secara pribadi maupun sebagai kelompok masyarakat selalu berinteraksi dengan lingkungan di mana ia hidup, dalam artian manusia dengan

Achmad Bahroni, Hak Penambangan Pasir OLeh Masyarakat Lokal Di Kecamatan Plosoklaten Kabupaten kediri 
berbagai aktivitasnya akan mempengaruhi kehidupan manusia. Manusia adalah sebagian dari ekosistem, manusia adalah pengelola pula dari sistem tersebut. Kerusakan lingkungan adalah pengaruh sampingan dari tindakan manusia untuk mencapai suatu tujuan yang mempunyai konsekuensi terhadap lingkungan. Pencemaran lingkungan adalah akibat dari ambiguitas tindakan manusia. Manusia telah memasukkan alam dalam kehidupan budayanya, akan tetapi ia nyaris lupa, bahwa ia sendiri sekaligus merupakan bagian dari alam, di mana ia hidup.

Menurut Kamus Hukum, pengertian masyarakat adalah setiap kelompok manusia yang telah hidup dan bekerja bersama cukup lama sehingga mereka dapat mengatur diri mereka dan menganggap diri mereka sebagai suatu kesatuan sosial dengan batas-batas yang dirumuskan dengan jelas. Sedangkan masyarakat lokal adalah kelompok masyarakat yang menjalankan tata kehidupan sehari-hari berdasarkan kebiasaan yang sudah diterima sebagai nilai-nilai yang berlaku umum tetapi tidak sepenuhnya bergantung pada sumber daya pesisir dan pulau-pulau kecil tertentu.

Berdasarkan hasil wawancara penulis dengan Elok Etika,S.Sos,MM yang merupakan Ketua Lembaga Pemberdayaan Masyarakat (LPM) beliau tidak setuju dengan adanya kegiatan penambangan pasir tersebut dikarenakan telah merusak lingkungan sekitar, yakni rusaknya jalan dan drainase akibat truk-truk pengangkut pasir, tanah di sepanjang pinggiran sungai menjadi longsor, dan bila musim hujan tiba akan terjadi banjir dan sungai meluap dan semakin melebarnya pinggiran sungai, beliau sangat berharap adanya tindakan tegas dari pemerintah setempat dan segera menertibkan para penambang pasir (Wawancara, Senin 30 Oktober 2017).

Dikuatkan pula oleh Sipali yang merupakan masyarakat di sekitar daerah penambangan pasir mengatakan bahwa awalnya Kepala Lingkungan tidak setuju dengan kegiatan penambangan pasir tesebut, akan tetapi karena menarik retribusi setiap truk yang mengangkut pasir akhirnya kepala lingkungan melakukan pembiaran terhadap kegiatan penambangan pasir tersebut. Lebih jauh lagi dijelaskan oleh Budi Santoso yang merupakan Kepala Lingkungan di Kelurahan Sepawon mengatakan bahwa kegiatan penambangan pasir tersebut telah berlangsung lama secara turun temurun dan beliau selaku kepala lingkungan tidak

Achmad Bahroni, Hak Penambangan Pasir OLeh Masyarakat Lokal Di Kecamatan Plosoklaten Kabupaten kediri 
dapat bertindak tegas terhadap kegiatan tersebut karena menjadi salah satu mata pencaharian masyarakat lokal di daerah tersebut, bahkan menjadi mata pencaharian utama bagi sebagian penambang pasir.

Menurut salah satu keluarga dari penambang pasir yang di wawancarai bahwa pemerintah setempat seharusnya lebih memperhatikan kondisi dan hak para penambang pasir, serta memberikan modal usaha bagi para penambang pasir di Kecamatan Plosoklaten, mengingat minimnya penghasilan yang diperoleh dari kegiatan menambang pasir tersebut (Wawancara, Senin 30 Oktober 2017). Di satu sisi kegiatan penambangan pasir mendatangkan manfaat ekonomi bagi masyarakat lokal, namun di sisi lain kegiatan penambangan pasir tersebut kurang memperhatikan aspek sosial dan lingkungan hidup, hal ini sesuai dengan asas berkelanjutan dan berwawasan lingkungan dalam penambangan mineral dan batu bara yakni secara terencana memperhatikan aspek ekonomi, lingkungan, dan sosial budaya untuk mewujudkan kesejahteraan masa kini dan masa mendatang.

Dalam hal menyangkut masyarakat dan lingkungan hidup, setiap orang berhak atas lingkungan hidup yang baik dan sehat sebagai bagian dari hak asasi manusia dan seseorang berkewajiban memelihara kelestarian fungsi lingkungan hidup serta mengendalikan pencemaran dan/atau kerusakan lingkungan hidup, hal ini sesuai dengan Pasal 65 dan Pasal 66 Undang-Undang. No. 23 Tahun 2009 tentang Perlindungan dan Pengelolaan Lingkungan hidup.

Untuk menumbuhkan peran serta masyarakat dan kesadaran para penambang pasir di Kecamatan Plosoklaten dalam pengelolaan lingkungan hidup bukanlah hal yang mudah. Untuk merealisasikan hal tersebut diperlukan berbagai usaha yang semestinya dilakukan pemerintah setempat seperti misalnya penyuluhan yang dilakukan secara berkesinambungan untuk meningkatkan pengetahuan dan pemahaman masyarakat dan para penambang pasir akan arti pentingnya menjaga kelestarian fungsi lingkungan hidup.

\section{Kebijakan Pemerintah Terhadap Pelaksanaan Hak dan Kewajiban atas Kegiatan Penambangan Pasir}

Didalam Undang-undang di atur dalam pasal 14 Undang-Undang No. 5 Tahun 1960 tentang Peraturan Dasar Pokok-Pokok Agraria bahwa terdapat

Achmad Bahroni, Hak Penambangan Pasir OLeh Masyarakat Lokal Di Kecamatan Plosoklaten Kabupaten kediri 
pengaturan penguasaan dan penggunaan tanah untuk kawasan tertentu berdasarkan rencana umum mengenai persediaan, peruntukan, dan penggunaannya, baik yang disusun perencanaannya oleh pemerintah pusat maupun pemerintah daerah. Dalam kegiatan pertambangan, rambu-rambu yang harus diperhatikan adalah kesesuaian dengan rencana tata ruang wilayah. (Berdasarkan hasil wawancara Tanggal 30 Oktober 2017) menurut Mashari selaku Kepala Desa Pranggang Kecamatan Plosoklaten, bahwa lokasi pertambangan pasir di Kecamatan Plosoklaten tidak termasuk dalam Wilayah Usaha Pertambangan (WUP) sesuai dengan rencana tata ruang wilayah Kabupaten Kediri.

Selain itu, Peneliti juga mengadakan wawancara pada Dinas Perindustrian Perdagangan Pertambangan dan Energi (Perindag Kediri) Kabupaten Kediri, menurut Abdul Sykukur selaku Staf Bagian Pertambangan bahwa kegiatan pertambangan pasir yang dilakukan oleh sebagian masyarakat Kecamatan Plosoklaten tersebut telah berlangsung sejak dulu dan turun temurun serta tidak memiliki izin dan para penambang pasir tidak pernah melakukan pengajuan Izin Pertambangan Rakyat. Dinas Perindag Kabupaten Kediri juga telah melakukan peneguran secara lisan dan melakukan sosialisasi mengenai pembinaan dan pengawasan di bidang keselamatan dan kesehatan kerja kepada para penambang pasir akan tetapi para penambang pasir terkesan acuh bahkan tidak mengindahkan teguran dari pemerintah setempat.

Keberadaan sektor pertambangan seperti pertambangan pasir, sebagai salah satau sumber daya alam yang tidak dapat diperbaharui sangat diperlukan untuk menunjang pembangunan. Menurut M. Sukadi selaku Kabag. Hukum Kabupaten Kediri bahwa dari sisi lingkungan hidup, pertambangan dianggap paling merusak dibanding kegiatan-kegiatan eksplotasi sumber daya alam lainnya, oleh karena itu sebagai kegiatan pertambangan rakyat, para penambang pasir mempunyai tanggung jawab yang besar terhadap upaya pemulihan lingkungan untuk menjamin kelestarian fungsi lingkungan hidup (Wawancara, Selasa 31 Oktober 2017)

Berdasarkan hasil penelitian ditemukan bahwa para penambang pasir tidak melakukan kegiatan rehabilitasi pasca tambang dan kegiatan reklamasi berupa

Achmad Bahroni, Hak Penambangan Pasir OLeh Masyarakat Lokal Di Kecamatan Plosoklaten Kabupaten kediri 
pemulihan lahan bekas tambang dan mempersiapkan lahan bekas tambang untuk pemanfaatan selanjutnya. Para penambang pasir hanya memasang bambu di bibir sungai sebagai penahan yang dimaksudkan agar tanah untuk menimbun pasir hasil tambang tidak longsor. Mereka tidak mempedulikan dan memperhatikan bagaimana cara mengelola lingkungan hidup yang baik agar usaha pertambangannya tidak mengakibatkan atau meminimalisirkan dampak negatif yang ditimbulkan pada fungsi lingkungan hidup. Hal ini tidak bisa dibiarkan begitu saja sebab setiap seseorang memiliki kewajiban terhadap lingkungan hidup yang sesuai dengan Pasal 67 Undang-Undang No. 32 Tahun 2009 tentang Perlindungan dan Pengelolaan lingkungan Hidup.

Adapun yang menjadi alasan penyebab masyarakat lokal yang melakukan penambangan pasir kurang memperhatikan aspek kelestarian fungsi lingkungan adalah:

1. Faktor pendidikan yakni kurangnya pengetahuaan, pemahaman dan tingkat pendidikan yang rendah para penambang pasir terutama di bidang hukum.

2. Faktor ekonomi yakni para penambang pasir rata-rata berpenghasilan minim dan golongan menengah ke bawah, penghasilan yang diperoleh dari menambang pasir relatif minim sehingga mereka beranggapan bahwa usaha yang dilakukan tidak akan berdampak luas terhadap lingkungan sekitar.

Saat ini pemerintah daerah mempunyai hak untuk mengelola sendiri daerah yang mereka kuasai (asas desentralisasi), sistem ini lebih dikenal dengan sebutan otonomi daerah. Hal tersebut sesuai dengan Pasal 1 Ayat (5) Undang-Undang Republik Indonesia Nomor 32 Tahun 2004 Tentang Pemerintahan Daerah yang menegaskan bahwa: "Otonomi daerah adalah hak. wewenang, dan kewajiban daerah otonom untuk mengatur dan mengurus sendiri urusan pemerintahan dan kepentingan masyarakat setempat sesuai dengan peraturan perundang-undangan”.

Di dalam Undang-Undang No. 32 Tahun 2004 ditegaskan bahwa pemerintah daerah dalam penyelenggaraan urusan pemerintahan memiliki hubungan dengan pemerintah dan dengan pemerintah daerah lainnya. Hubungan tersebut meliputi hubungan wewenang, keuangan, pelayanan umum, pemanfaatan sumber daya

Achmad Bahroni, Hak Penambangan Pasir OLeh Masyarakat Lokal Di Kecamatan Plosoklaten Kabupaten kediri 
alam, dan sumber daya lainnya. Hubungan keuangan, pelayanan umum, pemanfaatan sumber daya alam, dan sumber daya lainnya dilaksanakan secara adil dan selaras. Berkenaan dengan ketentuan tersebut, Pemerintah Daerah Kabupaten Kediri mengeluarkan Peraturan Daerah Nomor 14 Tahun 1998 tentang Pajak Pengambilan dan Pengolahan Bahan Galian Golongan C dan Keputusan Bupati Nomor 351 Tahun 1998 tentang Juklak Perda Nomor 14 Tahun 1998.

Masalah pengawasan dan pembinaan di bidang pertambangan, secara umum telah menjadi wewenang dan tanggung jawab Pemerintah Daerah Kabupaten/Kota yang penanganannya diatur dengan Peraturan Daerah (Perda) berdasarkan asas desentralisasi. Sesuai dengan Peraturan Daerah Kabupaten Kediri Nomor 14 Tahun 1998 tentang Pajak Pengambilan dan Pengolahan Bahan Galian Golongan C bahwa setiap usaha pertambangan Bahan Galian Golongan "C" baru dapat dilakukan apabila telah memperoleh Izin Usaha Pertambangan, Usaha Pertambangan Bahan Galian Golongan "C" dapat dilakukan oleh Badan Usaha Milik Negara (BUMN), Perusahaan daerah, Koperasi, Badan Hukum Swasta, Pertambangan Rakyat, dan Perusahaan dengan modal bersama.

Hal ini menunjukkan Pemerintah Kabupaten Kediri telah mengatur dan merencanakan setiap kegiatan pertambangan, yakni sebelum melakukan kegiatan pertambangan harus memiliki Izin Usaha Pertambangan (IUP) dan kegiatan penambangan pasir oleh masyarakat lokal di Kecamatan Plosoklaten di atur dalam Pertambangan Rakyat. Dari hasil wawancara dengan 5 orang penambang pasir yang menjadi responden penelitian ini, semuanya mengatakan bahwa tidak memiliki izin dalam melakukan kegiatan usaha pertambangannya dalam hal ini Izin Pertambangan Rakyat karena kendala biaya dan berbagai persyaratan/berkas yang harus dilengkapi saat pengurusan izin tersebut dan setelah itu harus membayar pajak kepada pemerintah setempat, sedangkan hasil dari menambang pasir itu sendiri masih sangat minim untuk memenuhi kebutuhan sehari-hari mereka.

Berdasarkan hasil penelitian ditemukan bahwa masih lemah dan kurang tegasnya aparat pemerintah khususnya pemerintah daerah dalam menegakkan dan menjalankan peraturan perundang-undangan yang ada. Pihak pemerintah terkesan melepas begitu saja para penambang pasir dalam melakukan kegiatannya tanpa ada

Achmad Bahroni, Hak Penambangan Pasir OLeh Masyarakat Lokal Di Kecamatan Plosoklaten Kabupaten kediri 
kontrol yang berkesinambungan. Menurut Abdul Syukur Staf Dinas Perindustrian Perdagangan Pertambangan dan Energi Kabupaten Kediri menyatakan bahwa selama ini tidak melakukan tindakan yang tegas serta peringatan/sanksi kepada para penambang pasir tersebut karena faktor ekonomi dan minimnya penghasilan dari penambang pasir (wawancara, Rabu, 1 November 2017).

Pemerintah setempat dalam hal ini pemerintah Kabupaten Kediri hendaknya melakukan pengembangan dan pemberdayaan masyarakat setempat dalam usaha pertambangan dengan memperhatikan kelestarian lingkungan. Mempertimbangkan berbagai peraturan Perundang-Undangan yang mengatur tentang Pertambangan, Lingkungan Hidup serta Peraturan Daerah, hak penambangan pasir yang dilakukan oleh masyarakat lokal tetap harus menjadi perhatian khusus bagi pemerintah setempat karena kegiatan pertambangan tersebut telah berlangsung sejak dulu dan terus menerus sehingga tanpa disadari akan menimbulkan dampak terhadap masyarakat dan lingkungan hidup di wilayah tersebut, serta memberikan peluang terhadap terjadinya perusakan fungsi lingkungan. Hal ini disesabkan karena pada umumnya para penambang pasir belum mengetahui bagaimana melakukan kegiatan penambangan yang baik dan benar yang penting bagaimana kebutuhan hidup tercukupi.

\section{KESIMPULAN}

Berdasarkan dari hasil pembahasan diatas, maka dapat disimpulkan bahwa :

1. Masyarakat selama ini melakukan penambangan pasir di Kecamatan Plosoklaten Kabupaten Kediri dengan penguasaan secara fisik dan secara alamiah dan turun temurun selama 20 tahun tetapi penguasaan secara fisik saja tidak cukup dan masyarakat di kecamatan plosoklaten Kabupaten kediri yang melakukan penambangan harus mempunyai izin Pertambangan Rakyat (IPR) yang bisa diurus oleh masyarakat itu sendiri di Pemerintahan Kabupaten Kediri yang tercantum dalam Pasal 1 ayat 10 Undang-undang No. 4 Tahun 2009 Tentang Pertambangan Mineral dan Batu Bara.

2. Bahwa dari sisi lingkungan hidup penambangan pasir secara liar harus dihentikan dan ditindak tegas sebab sangat merugikan untuk lingkungan hidup disekitarnya.

Achmad Bahroni, Hak Penambangan Pasir OLeh Masyarakat Lokal Di Kecamatan Plosoklaten Kabupaten kediri 
3. Pemerintah Kabupaten Kediri kurang tegas dalam menerapkan aturan-aturan yang dibuatnya yakni, PERDA No. 14 Tahun 1998 tentang Pajak Pengambilan dan Pengolahan Bahan Galian Golongan C dan PERDA No. 11 Tahun 2011 tentang Pajak Daerah. Hal ini disebabkan karena masyarakat lokal yang melakukan kegiatan penambangan pasir merupakan masyarakat ekonomi lemah dan hasil dari kegiatan menambang pasir itu sendiri masih sangat minim untuk memenuhi kebutuhan sehari-hari mereka, sehingga terjadi "pembiaran” oleh pemerintah setempat.

\section{SARAN}

1. Pemerintah harus memperhatikan keadaan/kondisi masyarakat lokal yang melakukan kegiatan penambangan pasir, sehingga seharusnya ada kebijakan lebih responsive yang lebih memihak kepada masyarakat setempat, mengingat kegiatan penambangan pasir tersebut merupakan mata pencaharian utama sebagian masyarakat penambang pasir.

2. Perlunya dilakukan penyuluhan hukum mengenai pertambangan dan lingkungan hidup kepada masyarakat lokal yang melakukan penambangan pasir agar mereka mengetahui hak dan kewajiban sebagai warga negara.

3. Pemerintah setempat tetap mendampingi dan memberikan arahan kepada para penambang pasir agar tidak menimbulkan dampak terhadap masyarakat dan lingkungan hidup di wilayah tersebut.

\section{Daftar Pustaka}

http://intisarihukum.blogspot.co.id/2010/12/hukum-administrasi-negaraperizinan.html

Takdir Rahmadi. 2011. Hukum Lingkungan di Indonesia. Jakarta: Rajawali.

Muhammad Akib. 2013. Hukum Lingkungan Perspektif Global dan Nasional. Jakarta : PT. RajaGrafindo Persada.

Undang-undang No. 4 Tahun 2009 tentang pertambangan Mineral dan Batu bara.

Achmad Bahroni, Hak Penambangan Pasir OLeh Masyarakat Lokal Di Kecamatan Plosoklaten Kabupaten kediri 
Undang-undang Nomor 32 Tahun 2004 pasal 4 ayat 4 tentang pemerintahan Daerah.

Undang-undang Nomor 32 Tahun 2009 Tentang Perlindungan dan Pengelolaan Lingkungan Hidup.

Achmad Bahroni, Hak Penambangan Pasir OLeh Masyarakat Lokal Di Kecamatan Plosoklaten Kabupaten kediri 